\title{
Engaging sexualities: Lesbian/gay print journalism, community \\ belonging, social space and physical place
}

\begin{abstract}
This article argues that lesbian/gay print journalism publications are strategically utilised by younger readers to forge a sense of community belonging. It is shown that such publications mediate an important dynamic between self-identity and group or community identity through motifs of belonging, engagement and access. Utilising interviews with younger readers of lesbian/gay journalism, it is argued that such publications are understood by readers as a public 'social space', but that a strong desire to engage in lesbian/gay in a local, geographic and physical sense is identified by the readers, suggesting that such publications perform an important but incomplete role in the construction of sexual identity and community belonging.
\end{abstract}

ROB COVER

Victoria University of Wellington

7 HE ROLE of lesbian/gay print journalism, its codes of production and distribution, reception by audiences, and its relationship with commu-

nity belonging and community space have been relatively ignored in academic research on both 'community print media' and the formation and maintenance of lesbian/gay (GLBT or queer) community identity, particularly in the Australasia-Pacific region. In international terms, research into lesbian/gay media formations has generally been limited to analyses based on a perceived similarity between this medium and other forms of ethnic community media, taking these formations as community institutions which 
archive the history of a spatially-located community enclave and provide a communicative network for the maintenance of that community and its bounds. Such studies rarely consider the ways in which the lesbian/gay press has been utilised by younger readers for the formation and maintenance of a sexual identity; as queer theorist Cindy Patton indicated more than a decade agoand her critique applies still today - the importance and role of the gay media in generating the gay/lesbian subject in post modernity has yet to be theorised' (Patton, 1991, p. 386n1). A number of writers have indeed addressed the ways in which lesbian/gay print news media have contributed to the formation of community and community identity. In the introduction to his history of the gay press in North America, for example, Rodger Streitmatter suggests that periodicals distributed by lesbian/gay community organisations explicitly for a lesbian/gay audience serve to help 'gay people identify themselves' (Streitmatter, 1995, xiii). Likewise, John D’Emilio in his Sexual Politics, Sexual Communities (1998) pays considerable attention to the formative role of the lesbian/gay print press. However, most writing on the communitarian role of lesbian/gay journalism leaves intact a humanist or essentialist idea of identity and community whereby community is understood as the gathering of pre-existing identities rather than a means by which such subjectivities are formed, performed and played out.

No matter what theory of identity formation of hetero- and homo- sexual identities is deployed — whether it be biologically essentialist, socialisational, constructionist, more recent theories of identity performativity or a combination of these - all depictions of identity and the forging of communities based on marginal identities require some sort of source for the performance and mutual recognition of groups and group belonging. That is, codes of behaviour and a 'sense' of self-identity based on sexual marginality are necessary in producing and performing a recognisable, intelligible and coherent identity. In the case of lesbian/gay identities, the role of lesbian/gay print journalism has been significantly underestimated as a resource used for the production of a coherent personal identity and the forging of a sense of 'belonging' (Cover, 2002a). Belonging is an increasingly important motif in much recent post-structuralist and cultural studies work (Probyn, 1996), particularly since it is a notion which, when understood in its greatest complexity, can be seen to play a broad constitutive role in the formation and maintenance of an identity-community dynamic, or what might alternatively be articulated as the 
identification between a labelled self-identity and a community group identity. Belonging works as an interface between the articulation of an identity and a represented community, and it is to be considered the condition of sexual identity coherence in contemporary Western cultures: the requirement that an intelligible and recognisable sexual identity is performed along either heterosexual or homosexual terms, and that a sense of group affiliation in some format, whether institutionally legitimated or identifiably marginalised, is adhered to. The important contribution of a cultural studies argument on sexuality and community media readership is one which acknowledges the need never to foreclose on alternative sexualities (those that fall outside the discursively-produced hetero/homo binary [Sedgwick, 1990]) while at the same time suggesting that (a) available discourses of sexual identity are constituted within media circulation and, yet, (b) readership is both complex and diverse, such that the norms, codes and conventions governing a coherent sexual identity cannot ever be wholly contained within the textuality of media publication or the codes and rhetoric of lesbian/gay journalism.

I am arguing in this paper that various media formations, and particularly the lesbian/gay press, are strategically utilised to mediate the dynamic between identity, as a recognisable personal 'performance', and community as an identifiable group held together by a set of symbols, rituals, institutionalised behaviours and norms, whether enacted through specific social spaces such as media audiencehood or geographically-local public space. Questions of the 'accuracy' of portrayals of lesbian and gay youth are not of interest here, partly because this sort of analysis does not cater for investigating the distortion of a media text from some alleged 'real'-which is always constituted in a series of other texts - and partly because the dominant interests here are the ways in which lesbian/gay print media are made use of as a 'resource' for the codes and conventions of lesbian/gay identities as they are located in notions of community and community place. Where media forms are touted as providing a community of difference from a geographicallylocated and place-bound sense of 'local community', I discuss the effectiveness of this media form in providing a sense of community through belonging that is forged in the act of media readership to varying degrees of efficacy, and vital to the performance of a coherent GLBT identity. In the latter half of the paper I work with material drawn from interviews of younger readers of Melbourne-based lesbian/gay community media in order to demonstrate a 
particular set of attitudes which inform my understanding of the utilisation of this media form as a resource for the production of coherent lesbian/gay identities.

\section{Identity, community and media}

Lesbian/gay press publications of the 1990s are the product of two early definable 'formats': political broadsheets distributed to draw attention to homophobia, bigotry and political motivation (Streitmatter, 1995, p. xiii), and nonpolitical newspapers - sometimes referred to as 'bar rags' - carrying advertising, venue locations, bulk 'classified personals' and, less ostensibly, providing gay cultural resources. The majority of lesbian/gay periodicals in western Pacific regions today combine elements of both styles and frequently view their institutional role as one of responsibility to report relevant information to a perceived lesbian/gay audience as well as to provide a space for community development and discussion. Incorporating more professionalised journalism techniques (Goddard, 1996, p. 2) and, in some cases, glossier production values resulting from increased advertising revenue and reduced production costs (Altman 1982, p. 20), the formats of lesbian/gay city-based newspapers and lifestyle magazines are recognisable and standardised in the United States, Britain and Australia. The most simple and common understanding of the community role of these publications is to report on both community events, trends, broader media depictions of lesbian/gay themes, issues and characters, and political matters that might affect that community - in other words, an arbitrary but broadly-defined notion of what constitutes lesbian and gay 'news', and an uncomplicated notion of the role of the media form as community institution.

The specificity of lesbian/gay print news journalism remains, particularly in an age in which the Internet is increasingly replacing local and tangible media forms with international or global and digital dissemination. This specificity - and perhaps also the reason why such media continue to be produced in spite of low profit margins (Goddard, 1996) - is through the difference between community 'news journalism' that presents concrete information on a local and tangible community of persons in a city-based regions and entertainment/information that is the form lesbian/gay digital media most often takes and that is often presented as youth coming-out resources, global political information such as same-sex marriage rights and the United States' state 
and federal politics. The exclusivity of the gay print press as compared with contemporary internet media can also be mapped against a local/global dichotomy whereby two 'types' of community are invoked: the local and geographically bounded lesbian/gay community and the diasporic and global construct of a lesbian/gay community that is without location but predicated purely on sexual identities of difference and exclusion. The majority of interviews discussed in the latter half of this essay indicated a strong interest in the local and the idea of local news in preference to ideas about resources. This would certainly point towards a sense by younger persons that locality and geographically-bounded sexual communities are constructed differently from more globally-marked diasporic communities, and that media representations of the geographically-accessible with its venues, insitutions and accessibility might well be of greater use in the construction of of sexual identities of difference than digital representations of lesbian/gay political and entertainment resources.

Effectively, the self-stated community role of local papers - often through self-consciously invoking the term 'Gay Community' or 'GLBT Community' as part of the masthead - recognises lesbian/gay print journalism as a localised or minoritised 'fourth estate' with equal responsibility with other branches of community and minority political governance. However, to leave this particular governmental role intact and un-theorised makes little sense for the media of a lesbian/gay community, since there are no 'official' or 'democratically authorised' forms of governance within such a community, unlike other community formations such as nations or local urban and suburban communities, is represented by local councils. However, there do exist certain forms of community 'leadership' in contemporary lesbian/gay cultures, each legitimated by various discursive formations, and which might include lesbian or gay elected members of legislatures, prominent spokespersons appointed through media utilisation of such persons for commentary, and others in privileged representative positions (Cover, 2002). Taking community figures into account, and witnessing lesbian/gay journalistic interrogation of those figures, provides a perspective on lesbian/gay community media as one whose role is implicated in pseudo-forms of community governance (Goddard, 1996). In that sense, Fourth Estate analyses have an appropriate role to play in determining the relationship between lesbian/gay community media and the legitimisation of its semi-established leadership institutions. Such a perspective 
on lesbian/gay media gives them a privileged and significant role in terms of lesbian/gay activist, community and emergent cultural policies, but tends to ignore the ways in which the media are implicated in the formation and maintenance of 'community' in terms of its audiences.

It is through looking to audience utilisation of the lesbian/gay journalistic press that we come to a broader understanding of its role in community formation and governance. The important work by Benedict Anderson (1983) on nationalism and nationhood draws the role of media closer to the concept 'community' by pointing to its formative constitution in, among other factors, daily print media. When Anderson writes that the nation as a form of community is imaginary, he usefully provides a view of the community as a cultural construct, imagined through various social institutions including media formations and the frequent, periodical reading of (print) media as a ritual through which community identities are narrated. For Anderson, national daily newspapers are central to the construction of a national community, and can be viewed as fictional cultural products which arbitrarily link, include and juxtapose separate events, thereby manufacturing a coherence and consistency between them (Anderson 1983, p. 33). Under this view, lesbian/gay press publications are seen to establish linkage of various narratives of identity and belonging; and frequently in terms of the distribution differences between different publications. Local journalistic work will present a ritualised turnover of news in weekly or fortnightly in releases in most cities in Australia, the United States and New Zealand, and large glossy lesbian/gay lifestyle magazines such as Advocate in the United States or DNA in Australia will be released monthly. The first presents a notion of a localised, accessible city-based community, although lesbian/gay-relevant news is presented from other (often international) regions, and the glossy magazines with a national or international distribution lend the illusion of a lesbian/gay or GLBT 'diaspora' across the globe (Sinfield 1996). Both are forms of belonging, and neither are exactly the same: the use of the term GLBT Communities invokes the idea of parallel local communities and a global ethnic-style grouping or category of personhood. The local community is presented as that to which a reader belongs depending on city of residence, use of (or at least access to) local lesbian/gay venues and other institutions (book launches, reading groups, youth groups, HIV/AIDS advocacy councils), and the local 'political' organisations which advocate variously though most often under liberal-humanist 
lobbying terms for legislative change, legislative protection and as a watchdog against various discriminations - the latter being a role shared with the local lesbian/gay journalists. Both sorts of publications make a set of secondary links through the intended audience, a 'lesbian and gay' or 'GLBT' or 'queer' audience which is understood and addressed as community — a result not only of the 'topical news' function of the lesbian/gay press, but also of directed advertising and identifiable niche marketing - fixtures of a western capitalist economy on which the economic survival of the larger lesbian/gay publications is based.

What I want to suggest here is that in addition to 'Fourth Estate' and Anderson's 'imagined community' understandings of the lesbian/gay press, there is a third position on this media form's role in community formation: that lesbian/gay print media provide a very powerful 'node' in an intensive dynamic operating between the concepts of identity and community, or between the forging of a personal sexual identity with a group identity culturally-given as an imagined 'community' in lesbian/gay community media. Rather than viewing communities as the natural, socialised or constructed public sphere 'gathering' of individuals of cultural, ethnic or lifestyle similarity, the construction of a specific group such as the lesbian/gay community is to be understood as discursively prior to the identities it claims to gather in its name. That is, community media provide more than a set of community institutional resources and forge more than just a sense of belonging among discrete already-identifiable individuals but, for many readers, are central to the affirmative construction of identities which are (a) seen in some cases to be performative rather than fixed and essential and (b) understood through the concepts of belonging, community access and community space and place. Identities are thus constituted in the interface between the personal and the group whereby self-identity and identification take place for belonging, rather than belonging being the natural result of gathered identities.

This point becomes more fertile when we take into account Judith Butler's theories of identity performativity. For Butler (1990, 1993), all identities are illusions with no natural or bodily foundations. Lesbian and gay identities, like gendered and ethnic identities, are performative, in the sense that they are 'performed' or 'played out' in accord with given cultural codes, norms and categories through the citation of the culturally-given signifier or name, under the rubric of fulfilling the broad cultural imperative of coherence and 
recognisability for the sake of belonging. Lesbian/gay performative identities differ from other identities by virtue of several facts: firstly, resulting from a continuing regime of censorship of sexuality from children and the disavowal of childhood sexual behaviour, a particular and culturally-legitimated age is reached at which one first encounters discourses of sexuality and is subsequently expected to articulate a sexual identity (hetero or homo, the former continuing most frequently as the 'expected' position). Secondly, unlike national or ethnic components to the performance of a coherent selfidentity, homosexual codes, behaviours and signifiers are acquired not in the usual disciplinary institutions such as family or school, but through access to various lesbian/gay cultural institutions and, more recently, through various media forms (Greenburg et al., 1993, p. 209, table 5). Finally, self-identity coherence requires that lesbian/gay identities are reiteratively performed through — in part — acting out lesbian/gay cultural norms of desire. This will often require utilisation of particular spaces, bonds, networks, institutions, venues, communicative forms and acts required for meeting and thus performing the ritual and sexual aspects of lesbian/gay identity. Although not all people who engage in same-sex sexual activities are necessarily homosexual, it remains that for homosexual identity strong communal bonds are invoked, whether that be in a bodily sense or through a 'mediated' form of community belonging.

The important point here is that in the performativity of an identity, a signifier or category must be engaged, resulting in the possibility of presenting a coherent lesbian or gay identity. What is engaged - or cited, to use Butler's term - is not a discrete notion of lesbian or gay identity, an identity or identifiable personage, but a community or group identity. It is through a spurious assertion of commonality and similitude that the identity is performed, relying ultimately on a prior notion of symbolic community. Such commonality or belonging, for Elspeth Probyn, is expressed as a desire for 'more than what is,' (Probyn 1996, p. 6). It is peaked for those who are 'already outside' in some way (Probyn 1996, p. 8), and for younger lesbian and gay people, an outsider status is already established by virtue of whatever spurious desires might be expressed outside of traditional cultural heteronormativity. For Probyn, we need to ask 'what identity really is for' (Probyn 1996,p. 9), and the finding is that it is for an affirmative sense of belonging as an engagement with an identity-community nexus that works to provide the necessary intel- 
ligibility of an identity. When this point is taken alongside Butler's theories of identity performativity, the impetus to perform a coherent, culturally-given and intelligible identity, to articulate one's 'self' as this or that sort of self, is conditioned by an imperative to belong (to something). It is in this sense that community journalism provides an important role in conditioning that engagement between self-identity and community identity. Belonging is central to the identity/community bond, but it is always a process and one that depends on a network of knowledges that are best provided through the ritual of engagement with a media form that simultaneously provides the codes for identity performance and the definitions of community. In other words, for belonging to 'work' the codes that make an identity performance intelligible and coherent in the terms of a category of community are provided through conceiving of media as a set of social spaces.

For many, the point of first contact with the codes providing behavioural and moral resources to articulate coherent lesbian or gay identities are to be found in the lesbian/gay print press (Fejes, 1997; Fejes \& Lennon, 2000). It is not only through the fact that lesbian/gay print periodicals are often the first place in which those who will come to perform lesbian/gay identity encounter the symbols of community, but also that community is symbolised in the form and content of the lesbian/gay press and that the ternary trinity relationship identity-community-media comes to govern the formulation of lesbian/ gay community. It is in the inseparability of the personal identity and the group or community identity for the sake of belonging that this media form plays a pivotal role when understood not as something which is produced but as something which is actively read. In a pilot study of readers of lesbian/gay periodicals, it was found that many actively sought out publications, lesbian/ gay newspapers and other print materials in order to join a particular, community public sphere prior to accessing a lesbian/gay public in a localised, physical and geographical sense (Cover, 2002a). It can be argued, indeed, that lesbian/gay print journalism operates as a powerful resource for the construction of identity, particularly as compared with internet resources, through its ostensible 'disguise' as news media. Rather than providing a 'coming out' guide that provides specific youth-oriented information on behaviours, safesex rules or historical accounts of lesbian/gay politics, it presents significant coverage on politics, legislation, public entertainment, venues, bars, clubs and gatherings. This coverage will have ostensible impact on a person in that 
region, community or country, and is physically accessible to the reader (regardless of whether such readers do indeed utilise local venues and institutions or not). It is in the production of news as local knowledge that the representation of both community and belonging are presented in a way that, arguably, is better aligned with the physicality of sexual identity than in the case of a digital environment or a broader and less community-specific media formation.

\section{Ritual, affirmation and belonging}

Given the position described above, audience understandings of the lesbian/ gay press could be seen to provide significant insight into this nexus between community and the constitution of identity through a notion of belonging governed by lesbian/gay community print media. For the remainder of this paper I want to describe some audience research conducted in the form of interviews, with the aim of lending greater insight into the identity-community-media relationships as they centre on belonging and, later, on a notion of geographic-accessible space. What I want to show here is that the mediaprivileged position of directing the nexus between community as a "public sphere' and identity as a performance is one which is understood and selfconsciously appreciated by the youth audience who ascribe to the publications' stated role as a community institution. In 1999, I interviewed 20 young Australian university undergraduates, all recent members of Monash University's student association queer collective, and all of whom had professed a non-heterosexual sexual identity in the previous two years. Although these interviews were undertaken for a separate project (part of a preliminary analysis of identity performativity and media reception), many of the responses involved a significant and somewhat unexpected preoccupation with notions of community belonging, the role of community news providing a space in which to engage in a lesbian/gay public sphere, and the relationship between this experience and that of physically accessing lesbian/gay community institutions such as venues, clubs and bars. This can be taken as testimonial to the important but unstable dynamic between self-labelling and group identity belonging. This dynamic is strongly embedded in media and popular culture as a communicative set of technologies utilised to negotiate an engagement between notions of identity and the construction of a space of belonging.

Throughout these interviews, several complex sets of discourses are cued 
by certain terms, ideas and connotations provided by the 20 young interviewees. Significant among them are a 'sense' of the constructedness of identities, the constructedness of communities which come to be synonymous with the dynamics between personal and public/group identities, and the fact that 'place' continues to be a dominant factor in determining 'community', even when that community is conceived and accessed as 'virtual'. The issue of belonging proved to be a central preoccupation, and it was through a linguistic establishment of an inseparability between the I of lesbian/gay self-identity and the belonging of community that the dynamic is found best in the act of reading lesbian/gay print media. As Interviewee\#13 put it,

I tend to feel comfortable reading MSO [Melbourne Star Observer], because it's news and stuff about the people I belong with. A lot of what they write about directly affects me, like changes in the laws, things that are going on, and dance parties and clubs opening and closing. It's my community, and even if I'm not going out very often or seeing other gay guys around the place much, I feel like I belong to the community when I get to read MSO (Interview\#13).

In a similar vein, another interviewee suggested that a sense of community was integral to her self-articulation of lesbianism:

It was only after reading about other dykes in LOTL [Lesbians on the Loose] that I felt more comfortable about going out to queer venues. I still hadn't slept with a woman, I hadn't even kissed a woman, and I wasn't even sure how attracted I was to women. But once I started going out, reading LOTL and meeting other dykes, I finally decided I could use the word dyke for myself. I finally started thinking that if I was going to be any sexuality, that I must be a lesbian (Interview\#4)

What both of these accounts indicate is that in articulating a self-identity or 'personal' identity with a sexual component, a notion of public belonging to a 'group identity' is vital. In following performative accounts of sexual identity, it is through the imperative to perform coherence that the construction of community as given in lesbian/gay press publications becomes a key factor in the articulation and stabilisation of a sexually inflected self-image. In other words, it is not just about conforming to a categorical norm, but of situating one's personal sense of self within a viable group identity. 
In part, this occurs through processes of audiencehood and reception. For lesbian/gay publications, the 'community' is not only the collective of persons, identities and institutions on which it reports, but also its 'audience'. In much contemporary media theory audiences are, of course, a construct, whereby media publications assume a consensus among readers (Philo, 1993, p. 255). The term 'community media' as it appears on the masthead of many lesbian/gay periodicals represents the established link between audience and community. As Etienne Wenger has suggested, readers of a text share a 'mutual link to a common readership [that] creates a kind of community to which they see themselves as belonging' (Wenger, 1998, p. 182). This imagined community is constructed in ritual acts of readership, which places the reader's position as member of an audience into a relationship with his or her position as member of a community. The process of identification, then, is a negotiation between attempts to forge a self-identity with a non-heterosexual (lesbian or gay) 'component', as it were, and a community as a 'group identity'. Through the process of reading the community press the reader recognises that he or she is being 'hailed' and comes to negotiate his or her selfidentity (in process towards a sexual self) as a component of a group identity.

The younger readers of lesbian/gay journalism were strongly and selfcritically aware of the ways in which the process of forging a sexual identity of belonging through acts of readership operates as a process:

I subscribed to MSO [Melbourne Star Observer] for about six months. I can't remember how I got the subscription form but I did. It was really dangerous, because it would come to my mum's house every couple of weeks, and luckily she never opened any of my mail. . . . Why did I want to subscribe? Well, it was easier than going places to get a copy every week. . . . I used to get the paper and wait for everyone to go to bed, and I'd be in my room and just read it. Sometimes I'd read everything, sometimes just some of the pages over and over again. ... At first I felt a bit lost, but later I could really see things of myself in there. Sometimes in the little interviews with people, sometimes even in the pictures [of crowds in venues]. I wonder how many other people were doing exactly the same thing. . . . Sometimes I thought there must be thousands of people like me, too scared to go out and stuff, but lying there reading this paper. Thing was, I wasn't really sure I was queer until I'd be reading the paper. Sometimes I just had to read it to feel like I was properly queer (Interview\#13). 
This interview provides an exemplary account of the role of lesbian/gay print in forging a sense of belonging across a media form. By setting up a sense of community among other readers, the ritual process of reading is constitutive in directing an individual into the process of performing a specific sexual identity, one which remained unclear until the 'available discourses' of homosexuality were made accessible through the audience-community process.

What is perhaps most importantly indicated in the above interview extracts is a sense that the act of readership of lesbian/gay texts is not understood by the interviewees as part of a process or transmission model, but is better thought of as an act of ritual reading. For media theorist James Carey, a cultural approach to communication needs to dislodge the notion of the media process as purely transmissive, where such an act of comunication is seen as the extension of messages across geography for the purposes of disseminating news, knowledge or entertainment (Carey, 1988, pp. 18, 20). Where the interviewees speak of requiring information before confirming or articulating a lesbian or gay identity and subsequent belonging, what is being discussed is not merely an act of information-seeking but one of ritualised belonging. Carey's view is that a ritual process of reading is to be seen as a "sacred ceremony that draws persons together in fellowship and commonality" (Carey, 1988, 18). Where interviewee\#13, then, seeks information from the publication, his consideration of the potential other readers doing the same thing draws him into a sense of belonging, through the impetus of a search for the 'rules' of affirmation and similarity, under which an identity as gay can be articulated and confirmed.

\section{Media, 'space', community and identity}

In reading many of the interviews, it becomes quickly apparent that the role of lesbian/gay media institutions in constituting a sense of identity cannot be disconnected from the ways in which the media operates to construct community and, in many cases, to stand in for it. This process of the lesbian/gay media performs two regulatory functions: firstly as a governing institution of the community and secondarily as the access-point by which other institutions are represented for those with no effective means to access these institutions 'in person'.

As Interviewee\#13 says, 
I was reading the magazines and newspapers whenever I was staying at my parents' house, which is quite a long way from the city. Especially during the holidays, I couldn't easily get to clubs and groups because I couldn't guarantee having a place to stay at night. When I was reading, whenever it would arrive - because I was a subscriber - I would have something to feel like I belonged ... (Interview\#13).

In his later use of the lesbian/gay press, this interviewee establishes a role for the publications to operate a sense of belonging which compares with community activities which occur in physical spaces such as youth groups, bars and clubs. In his study of communications practices and various technologies, Joshua Meyrowitz articulates a blurring of distinctions between physical or geographic 'place' and the social 'space' opened up by contemporary communications practices.
A Place defined a distinct situation because its boundaries limited per- ception and interaction. Like all electronic media, the telegraph not only defies limits formerly set by distance, but also bypasses the social rite of 'passage,' that is, the act of moving both physically and socially from one 'position' to another.. (Meyrowitz, 1997, p. 43)

This motif allows us to view lesbian/gay print publications as a particular type of representation of the public places and geographic locations which have tended to define lesbian/gay community since the 20th century (Ingram et al., 1997). Where the lesbian/gay press arose to provide a political or communicative function for a lesbian/gay community, it has also come to work as a public sphere that links communities and discourses that are inaccessible due to distance or inability to travel.

Another recent motif that might be deployed to make clear this operation is that of 'virtual community', a term more readily deployed in studies of the internet and electronic interactive media forms. Other interviewees similarly articulated a sense of the virtuality of the community formation that is set up in the act of reading such publications.

I first found the magazines at a café near my work, and wanted to read them before I ever went out. I wanted to know what I should wear, how everyone else was going to behave. I suppose I just wanted to be able to go to clubs like The Market [Melbourne, Australia] without looking 
completely out of place. I was really scared that might happen, and really scared I wouldn't be allowed in or I'd get laughed at or something. It was years before I went there, and so I read magazines and stuff to feel like I was part of something gay (Interview\#5).

Thus while many of the interviewees articulated a sense in which they needed to see others and feel they belonged with those who were 'similar' to themselves, there is an implicit - and sometimes explicit — understanding that the group of others they see determines what they themselves become. In this particular case, there is an underlying awareness of the group identity as that to which one, in the process of performing or constructing the self, aspires through both imitation and a forged sense of belonging. For this interviewee, then, the lesbian/gay magazines could be said to provide the dual role of making available particular images, particular styles and particular ways of behaving as well as providing a ritual sense of belonging to a community in its virtuality as social space.

However, the view that community was the ground from which a personal non-heterosexual sexual identity could be forged was by no means universal among the respondents. Several argued that they felt little 'relationship with the community' (Interview\#6), while others suggested that involvement in the community, whether in spatial or relational terms, did not interest them, and one woman poignantly commented 'I might have sex with women, but I don't see myself belonging to anything, and particularly not to that world' (Interview\#20). When asked why they thus read lesbian/gay media, it appeared to be about providing something which approximated community belonging, even in the face of the possibility that it was not a community to which they necessarily desired to belong. In that sense, the social space that is invoked by lesbian/gay journalism is one which operates in some cases as a rehearsal for public place in a dichotomous hierarchy in which physical engagement with community is understood as the superior form of belonging.

\section{Virtual community, place and queer public space}

What is of particular interest in these accounts is the heavy reliance on a geographic sense of community. This was particularly apparent amongst those whose rehearsal of a non-heteronormative sexual identity must rely on reading lesbian/gay print media as a 'surrogate' virtual community substituting 
for direct attendance at venues and institutions, or a personal involvement in sexual activity and homosexual coupled relationships. This might suggest that the virtual or social space opened up by lesbian/gay publications does not necessarily provide the sense of belonging that a more interactive engagement with community in a physical locale might do.

In his analysis of communication, Raymond Williams suggests that there is "no form of social activity which the use of these [media] techniques has replaced' (Williams, 1997, p. 21). This is in line with the attitude of many of the respondents to the virtual or social space of community provided by the publications: while they often provide through ritual reading the sense of belonging crucial to the engagement between construction of the sexual self and group identity, they are frequently treated as a prelude to a more interactive engagement in physical space. This would have a lot to do with the fact that a lesbian or gay self-identity is still predicated on a sense of sexual activity or coupled relationship status which foregrounds bodily presence in some form of shared space, often public — or at least semi-public in the sense that it involves crowds of persons large enough that not all can be known without necessarily being identified as 'mass' (Williams, 1997). For example, Interviewee\#23 suggested the following:

I suppose in some ways I was interested in reading the lesbian paper because I wanted to learn more about sex before I actually went out and had any. It was good, because although there really wasn't very much about sex there, it did give me some ideas about what it was like and what I might look forward to when I actually got out there to meet other people (Interview\#23).

This out there as it is differentiated from the belonging of community paper readership would suggest the continuing importance of place. Identity it might be said insists on a live performance and the physical event rather than the communicative event.

In one case, it was not so much a matter of the physicality of homosexuality as sexual practice or coupling - as one means of shoring up or articulating a self-identity as lesbian or gay - but the failure of newspapers and magazines to provide more interactive communication. Many of the interviewees, and most particularly those who spent their childhood in rural areas, did not have immediate access to internet communications. ${ }^{1}$ Interview\#2 did, and 
had this to say about the lesbian/gay press:

Well, I've read it and I've seen it, but I don't think it ever had anything to do with me having a gay identity. When I was still in school I used to go in the gay chatrooms and talk to other people and stuff, and that was years before I ever actually met a single gay person. I don't really have much interest in these mags, because I'd much rather talk to other people, even if it's in chat. I actually got to know quite a few people who I met later, mostly in my last year of school. I don't think the mags would have been of much use to me when I was young, I probably wouldn't even have bothered. The internet had everything I needed (Interview\#2).

This might well indicate the future of lesbian/gay media-ted communicative practices, whereby internet further shortens communicative distance per Meyrowitz' thesis that media aid communication across geographies, changing the nature of distance and time. By dislodging the hassle or difficulty of gaining a newspaper subscription, or the physical collection of a lesbian/gay periodical, or the need sometimes to pay for it or, indeed, the difficulties in terms of safety that might be involved in accessing non-heteronormative material in a family or group household, the world wide web can provide a stronger access for engagement with community through ritualistic and reiterative communicative practices. By providing communication in a more interactive environment such as virtual chat or email, the ritual use of the media form provides a stronger sense of belonging. Nevertheless, as Interviewee\#2 indicates, it even still does not provide the same sense of belonging that physical engagement with community place will do.

What can be concluded from these accounts is that despite a contemporary surge in notions of a spaceless community or a virtual community, younger lesbian and gay readers continue to define the lesbian/gay public sphere in local-spatial or geographic terms, as a place rather than space. There are perhaps three ways in which this can be explained, all of which would require further study beyond the scope of the current article.

Firstly, we can think of the performativity of sexual identity as a performativity which invokes a specific cultural code of desire-sexual desire for another embodied subject. The practicalities of meeting partners (whether longer term or fleeting), cruising, picking up, having sex, and so on 
require not only a sense of community place, but actual engagement in that place physically. I am, of course, discounting cybersex here which may provide a comfortable and safe alternative but which in the more dominant discourses of sexuality is often articulated as secondary or 'virtual' - that is, not the 'real'. Certainly none of the interviewees considered cybersex a means by which to dislodge the need for engagement with others in physical places.

Secondly, the contemporary notion of lesbian/gay identity and community are often thought in terms of formations of minority ethnic community, thereby invoking the concept of the ghetto as a sort of sub-Mecca to make up for the loss of a 'real' homeland in a distant geographic space (Buchbinder, 1998; Epstein, 1990).

Thirdly, the failure of community - the unspoken fact that all communities are imaginary and may be always less than 'real' - suggests that there might be conduits through which the desire for belonging is continued. This would be to see this media (virtual) community as failure, or 'lack', although as many of the other interviewees suggested, the role in providing a sort of step towards physical place would indicate that lesbian/gay journalism has a significant if qualifiable role to play in the process of forging identity and belonging. Perhaps what this analysis indicates best, particularly in an age in which we must locate the lesbian/gay local print press in terms of the globalising formation of the internet, is that local and physically accessible community place as social space must be located in a continuum, but one which is contingent, historical and only recently emerging. At one pole on the continuum is the physically-accessed sense of community that is rooted in the concept of place, and at the other the digital or virtual forms of social space invoked by the internet, digital communications and other formations that are occasionally understood as the non-real or as 'lesser' forms of sociality. This would be to place the act of lesbian/gay community print readership somewhere between these poles, whereby the pull of the local and the focus on place is offset by the separation of place and social space.

\section{Note}

It is also possible to speculate here that lesbian/gay groups on a university campus, particularly those that are more socially-oriented than activist-political, are more often frequented by those students who have had little previous access to discourses of sexuality, the spaces, places and media texts that enable an engagement with community forms. 


\section{References}

Altman, D. (1982). The homosexualization of America: The Americanization of the homosexual. New York: St. Martin's Press.

Anderson, B. (1983). Imagined communities: Reflections on the origins and spread of nationalism. (2nd ed.) London: Verso.

Buchbinder, D. (1998). Queer diasporas. Unpublished paper presented at the Postmodernism in Practice Conference, Feb/March 1998, Adelaide.

Butler, J. (1990). Gender trouble: Feminism and the subversion of identity. London \& New York: Routledge.

Butler, J. (1993). Bodies that matter: On the discursive limits of 'sex'. London \& New York: Routledge.

Carey, J. (1988). Communication as culture: Essays on media and society. London \& New York: Routledge.

Cover, R. (2000). First contact: Queer theory, sexual identity, and 'mainstream' film. International Journal of Sexuality and Gender Studies, 5.1, 71-89.

Cover, R. (2002). Cultured borders, bordering cultures: Lesbian/gay culture, the Australian multicultural paradigm and 'the nations'. Word is Out 4. Retrieved March 18, 2003: http://www.wordisout.info

Cover, R. (2002a). Re-sourcing queer subjectivities: Sexual identity and lesbian/gay community media. Media International Australia (incorporating Culture \& Policy), 103, 109-123.

D'Emilio, J. (1998). Sexual politics, sexual communities: The making of a homosexual minority in the United States, 1940-1970. Chicago: University of Chicago Press.

Epstein, S. (1990). Gay politics, ethnic identity: The limits of social constructionism. In Stein, E. (Ed.), Forms of desire: Sexual orientation and the social constructionist controversy (pp. 239-93). New York \& London: Garland.

Fejes, F. \& Lennon, R. (2000). Defining the lesbian/gay community? Market research and the lesbian/gay press. Journal of Homosexuality, 39.1, 25-42.

Fejes, F. (1997). Reviews of E. Alwood, Straight news: Gays, lesbians and the news media, \& R. Streitmatter, Unspeakable: The rise of the gay and lesbian press in America. Journal of Homosexuality, 34.1, 105-110.

Foucault, M. (1990). The history of sexuality: An introduction. (Trans. Robert Hurley). London: Penguin.

Goddard, M. (1996). The whole truth: Limits on gay and lesbian journalism. In G. Wotherspoon (Ed.), Gay and Lesbian Perspectives III: Essays in Australian culture (pp. 1-16). Sydney: Department of Economic History, University of Sydney.

Greenburg, B. S., Brown, J. D., \& Buerkel-Rothfuss, N., (Eds.). (1993). Media, sex and the adolescent. Cresskill, NJ: Hampton Press Inc.

Ingram, G.B., Bouthilette, A., \& Retter, Y. (Eds.) (1997). Queers in space: Communities, public places, sites of resistance. Seattle, WA: Bay Press.

LaBruce, B. \& Belverio, G. (1996). A case for the closet. In M. Simpson (Ed.), AntiGay (pp. 140-163). London: Freedom. 
THE INDIGENOUS PUBLIC SPHERE

Lipsitz, G. (2001). Diasporic noise: History, hip hop and the post-colonial politics of sound in popular music. In C.L. Harrington \& D.D. Bieldy (Eds.), Popular culture: Production and consumption (pp. 180-201). Massachusetts: Blackwell.

Meyrowitz, J. (1997). The separation of social space from physical place. In T. O'Sullivan \& Y. Jewkes (Eds.), The Media Studies Reader (pp. 45-52). London: Edward Arnold.

Patton, C. (1991). Visualizing safe sex: When pedagogy and pornography collide. In D. Fuss (Ed.), Inside/Out: Lesbian theories, gay theories (pp. 373-386). London: Routledge.

Philo, G. (1993). Getting the message: Audience research in the Glasgow University Media Group. In J. Eldridge for Glasgow University Media Group (Eds.), Getting the message: News, truth and power (pp. 254-270). London \& New York: Routledge.

Probyn, E. (1996). Outside belongings. New York \& London: Routledge.

Sedgwick, E.K. (1990). Epistemology of the closet. London: Penguin.

Sinfield, A. (1996). Diaspora and Hybridity: Queer Identities and the Ethnicity Model. Textual practice 19(2): 271-293.

Streitmatter, R. (1995). Unspeakable: The rise of the gay and lesbian press in America. London \& Boston: Faber and Faber.

Sullivan, A. (1995). Virtually normal. London: Picador.

Williams, R. (1997). Mass and masses. In T. O'Sullivan \& Y. Jewkes (Eds.), The Media Studies Reader (pp. 18-27). London: Edward Arnold.

Dr Rob Cover is lecturer in media studies at Victoria University of Wellington. He researches and publishes on queer theory and media theory, new media interactivity and electronic gaming. He thanks the Monash Student Association, the Not Quite Straight queer students' support group and particularly its (1999) co-convenor Nathan Boyle for assisting with organising the interviews and permitting him to conduct them in his office.

rob.cover@vuw.ac.nz 